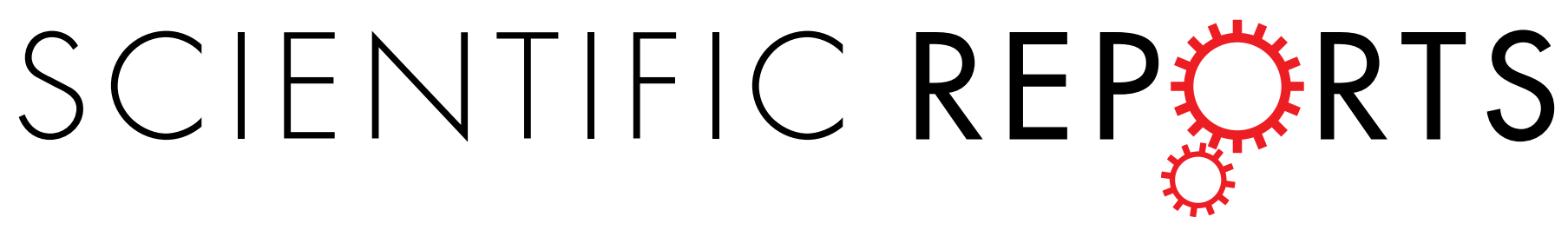

OPEN Corrigendum: An automated

\title{
approach to prepare tissue-derived spatially barcoded RNA-sequencing libraries
}

Anders Jemt, Fredrik Salmén, Anna Lundmark, Annelie Mollbrink, José Fernández Navarro, Patrik L. Ståhl, TülayYucel-Lindberg \& Joakim Lundeberg

Scientific Reports 6:37137; doi: 10.1038/srep37137; published online 16 November 2016; updated on 13 March 2017

This Article contains errors in Figure 6c. The Pearson correlation values for the automated and manually prepared samples were inadvertently switched. The correct Figure $6 \mathrm{c}$ appears below as Figure 1.

C
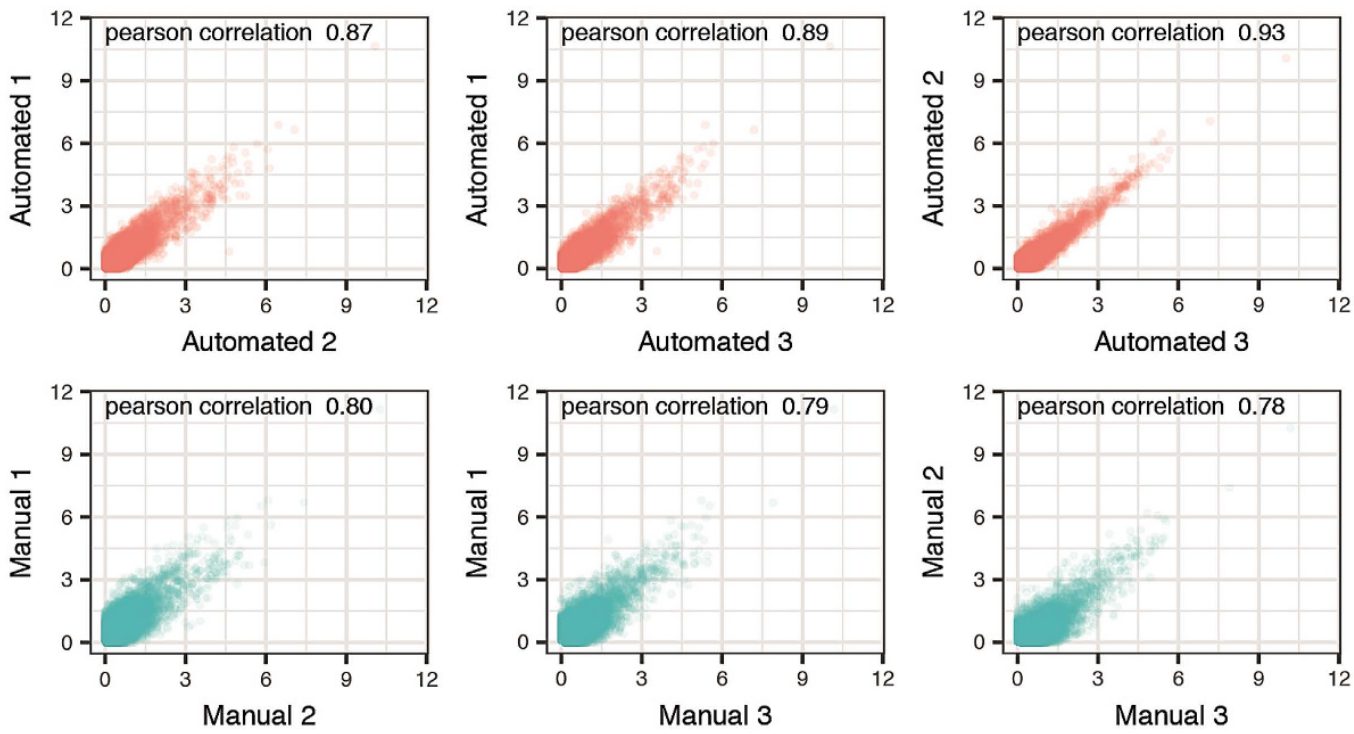

Figure 1.

(i) This work is licensed under a Creative Commons Attribution 4.0 International License. The images or other third party material in this article are included in the article's Creative Commons license, unless indicated otherwise in the credit line; if the material is not included under the Creative Commons license, users will need to obtain permission from the license holder to reproduce the material. To view a copy of this license, visit http://creativecommons.org/licenses/by/4.0/

(C) The Author(s) 2017 